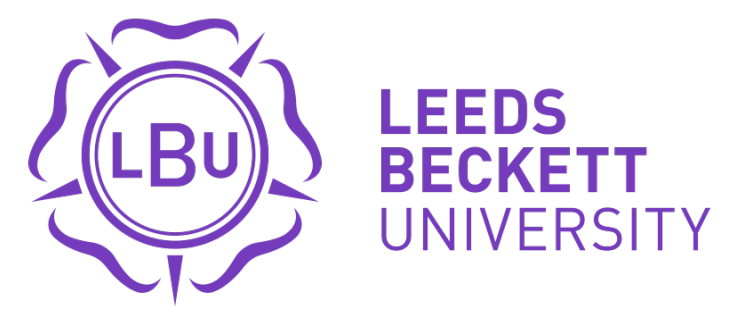

Citation:

Combs, A and Samy, M and Myachina, A (2013) Cultural impact on the harmonisation of Russian Accounting Standards with the International Financial Reporting Standards: A practitioner's perspective. Journal of Accounting and Organizational Change, 9 (1). 26 - 49. ISSN 1832-5912 DOI: https://doi.org/10.1108/18325911311307195

Link to Leeds Beckett Repository record:

https://eprints.leedsbeckett.ac.uk/id/eprint/1511/

Document Version:

Article (Accepted Version)

The aim of the Leeds Beckett Repository is to provide open access to our research, as required by funder policies and permitted by publishers and copyright law.

The Leeds Beckett repository holds a wide range of publications, each of which has been checked for copyright and the relevant embargo period has been applied by the Research Services team.

We operate on a standard take-down policy. If you are the author or publisher of an output and you would like it removed from the repository, please contact us and we will investigate on a case-by-case basis.

Each thesis in the repository has been cleared where necessary by the author for third party copyright. If you would like a thesis to be removed from the repository or believe there is an issue with copyright, please contact us on openaccess@leedsbeckett.ac.uk and we will investigate on a case-by-case basis. 


\section{Cultural impact on the harmonisation of Russian Accounting Standards with the International Financial Reporting Standards: a practitioner's perspective.}

\section{Introduction}

Harmonisation of accounting standards has been an important process in response to globalisation of capital markets. "The globalisation of capital markets and the developments in telecommunications and the internet bring new significance to the need for comparable and transparent financial reporting and require new thinking by companies, investors, creditors and auditors about what financial information companies should publish and how best to communicate it" (Nobes, 2001, p.3). Global accounting standards will enable investors to make better informed financial decisions, which in turn, could lead to a reduction in risks for investors and, an ultimate reduction in the cost of capital. In addition, global standards would lead to a reduction in multiple reporting obligations for the international companies, thus leading to an improved access to capital markets, reducing costs and eliminating complexities (Nobes, 2001).

Since 2005, the European Union has made the International Financial Reporting Standards (IFRS) compulsory for the consolidated accounts of all its listed companies (European Union, 2002). Similar policies have been introduced in other countries, including Russia. Since the early 1990s Russia has been undergoing a transition from a planned to a market economy. An important part of this transition involves changing its accounting system and harmonising Russian Accounting Standards (RAS) with the International Financial Reporting Standards. By the late 1990s the Russian government started the accounting system reform with the introduction of the "Programme for the reformation of accounting in accordance with International Accounting Standards" (Decree of the Russian Federation, 1998). However, to this day differences between the two sets of accounting standards still exist, which is hampering successful implementation of the harmonisation process. 
The crux of this research is to explore if culture has an impact on the harmonisation of Russian Accounting Standards with the International Financial Reporting Standards. Russia has a unique and transitional economic environment, as such the researchers are motivated to further contribute to the literature by understanding the motivation of users and preparers of financial reporting (Bagaeva, 2008). As stated by Harding and McKinnon (1997), the preparers' intention is reflective of the influence of the users as such culture can be explored as an integral factor in the process of accounting information. The contribution of this paper is to fill the gap to a cross country study that was undertaken on 52 countries where the findings conclusively argued that culture is a strong explanatory factor to harmonisation (Ding et.al., 2005). We feel that the current study explores further the explanatory factor deeply through the phenomological lens. This research took a post positivism philosophical view as it raised ontological questions in order to analyse the relationship of cultural perspectives of the accountants and its impact on their practices. Therefore the study endeavours to gather Russian accountants' attitudes and perceptions towards financial reporting under new harmonised RAS. Some of the differences that exist between the two sets of accounting standards are explored in the interviews whilst identifying what accounting value preferences are held by Russian accountants.

The first part of the paper provides a review of the literature. Firstly, the concept of culture is explained and linked to accounting. A review of international accounting research is then presented. Finally, a history of Russian accounting development to this day is outlined. This is followed by the methodology applied to collect and analyse the data. Finally, the findings and discussions are presented. 


\section{Literature Review}

The concept of culture is the least delineated construct and it is multidimensional and complex. As stated by Straub et.al. (2002, p. 14) culture "has always been a thorny concept and even a thornier research construct". Culture has been studied in many aspects such as values and value systems of individuals through interactions from family and society (Rokeach, 1973), and shared patterns of thinking and reacting to surroundings through symbols (Kluckholn, 1951). Building on the subjective term of shared values and patterns were researchers such as Triandis (1972) who developed the theoretical framework of human beings having a sense of belonging through identities such as occupation, beliefs, religion and language. Hofstede (1980) developed this theory further by conducting a global study to distinguish one human being from another.

\section{Hofstede’s Cultural Dimensions}

Culture has been defined as "the collective programming of the mind which distinguishes the members of one human group from another" (Hofstede, 2001, p. 9). In this definition the 'mind' refers to the head, heart and hands or thinking, feeling and acting, which consequently shape our attitudes, beliefs and skills (Hofstede, 2001). According to Hofstede, culture consists of values, which are invisible manifestations of culture, together with symbols, rituals and heroes, which are visible manifestations of culture.

Symbols, heroes and rituals are colligated under the term practices. This makes them visible to an external observer, however the cultural meanings they possess are invisible and can only be interpreted by insiders (Hofstede, 2001).

Hofstede conducted research which led to the development of five national cultural dimensions, which are Power Distance, Uncertainty Avoidance, Individualism and Collectivism, Masculinity and Femininity and Long versus Short-Term Orientation. Hofstede 
devised employee attitude surveys to analyse employee values in different countries and subsequently develop the cultural dimensions (Hofstede, 2001).

Power Distance is referred to by Hofstede as "the extent to which the less powerful members of institutions and organisations within a country expect and accept that power is distributed unequally" (2001, p.98). In countries with high Power Distance Index (PDI) scores inequality is seen as a norm and hierarchical order is essential with superiors given utmost respect with a hint of fear. Russia is considered a high-PDI country with a score of 93 and ranking $6^{\text {th }}$ out of 74 countries (Hofstede \& Hofstede, 2005, p.43). "Throughout Russia’s long and violent history, successive governments have allowed, and in some instances encouraged, and stimulated, inequalities of power and wealth" (Djatej, Sarikas \& Senteney in McGee ed., 2008, p.143). Shlapentokh (1996) draws a parallel between the contemporary Russian society and the existence of feudalism in the West between the ninth and twelfth centuries with property and power closely intertwined. In an organisational context "philosophy of a firm is connected to the philosophy of leadership, as the leader is the person who possesses the whole spectre of power, creates internal and external image of enterprises" (Akperov and Maslikova, 2002, p.7). The hierarchy amongst employees is rigid in Russian organisations with strict rules and procedures that need to be followed.

Uncertainty Avoidance according to Hofstede is "the extent to which the members of a culture feel threatened by uncertain or unknown situations" (2001, p.161). Societies with high-UAI (Uncertainty Avoidance Index) scores tend to be more conservative whereas lowUAI score signifies openness to change. People in low-UAI societies are normally able to direct their courses of lives themselves as compared with high-UAI societies where people tend to feel powerless towards external forces such as government and employers. Russia is considered as a high-UAI country with a score of 95 and ranked $7^{\text {th }}$ out of 74 countries (Hofstede \& Hofstede, 2005, p.168). Russia has undergone numerous radical changes and it 
left its people rather anxious as these constant changes brought instabilities, both political and economical (Djatej, Sarikas \& Senteney in McGee ed., 2008). Russians value the importance of traditions, history and past experiences greatly and "are accustomed to a high level of certainty" (Michailova, 2000, p.108). The next dimension is Individualism contrasted with Collectivism. Hofstede defined this dimension as follows: "Individualism stands for a society in which the ties between individuals are loose: Everyone is expected to look after himself or herself and his or her immediate family only. Collectivism stands for a society in which people from birth onwards are integrated into strong, cohesive in-groups, which throughout people's lifetime continue to protect them in exchange for unquestioning loyalty" (Hofstede, 2001, p.225). Russia has a score of 39 and is ranked $37^{\text {th }}-38^{\text {th }}$ out of 74 countries on this dimension (Hofstede \& Hofstede, 2005, pp.78-79), which signifies that its position is somewhat in the middle of the relative scale. However, research conducted by the Laboratory of Ethnic Sociology and Psychology of St. Petersburg between 1996 and 2000 showed that one of the predominant basic values of the Russian people was "collectivism as a preference for group as opposed to individual self-identification" (Russian Mentality: Uncertainty and Fatalism, 2002).

The Masculinity and Femininity dimension has been defined by Hofstede in the following way: "Masculinity stands for a society in which social gender roles are clearly distinct: Men are supposed to be assertive, tough, and focused on material success; women are supposed to be more modest, tender, and concerned with the quality of life. Femininity stands for a society in which social gender roles overlap: Both men and women are supposed to be modest, tender, and concerned with the quality of life" (Hofstede, 2001, p. 297). Russia has a score of 36 and is ranked $63^{\text {rd }}$ out of 74 countries, which means it is a low-MAS index country (Hofstede \& Hofstede, 2005, pp.120-121). 
The fifth dimension of Long versus Short-Term orientation is not considered in the present study due to lack of data related to Russia on this dimension.

Baskerville (2003) reviewed studies that used Hofstede's cultural dimensions and found problems suggesting that international accounting research "requires systematic modelling of characteristics of nations based on well-established economic indices, as well as indices to take account of the nexus of historical and political tensions in each nation" (p.10).

McSweeney (2002) criticised Hofstede's methodology. He branded the survey not representative as it was derived from a single company. In addition, the data from the survey is now deemed to be outdated.

Despite all the criticisms, Hofstede's work remains one of the most cited in cross-cultural research and is used extensively in business and psychological research, and has been validated by numerous studies (Søndergaard, 1994). The authors argue that despite the criticisms, the cultural studies by Hofstede can be used as one of the bases for understanding the philosphical ideologies of practices and process within societies, given the studies which support them (Søndergaard, 1994), and their subsequent development in the work of Gray (1988).

\section{Accounting systems and Culture}

Accounting systems play an important cultural role in organisations (Hofstede, 2001). Accounting is seen by Hofstede as a field in which historically developed practices are more important than laws of nature. It is therefore expected that accounting rules and the way they are applied will vary among different national cultures. Hence, Gray (1988) tried to explore how Hofstede's national cultural dimensions may explain international differences in accounting. Gray (1988) proposed a framework linking the development of accounting systems internationally with culture. This model proposes that societal values, which are determined by ecological influences shaped by external factors, are expressed at the level of 
the accounting sub-culture. Therefore, value systems expressed as accountants' attitudes may relate to and derive from societal values with special reference to work-related values. Consequently, accounting systems will be influenced by accounting values (Gray, 1988).

Gray's model recognises however, that both accounting systems and the accounting values which inform them may also be influenced indirectly by societal values through their impact on what Gray terms 'institutional consequences'. For Gray, institutional consequences are the legal system, corporate ownership, capital markets, professional associations, education and religion (Gray, 1988).

Thus accounting values and accounting systems at the sub-cultural level may derive to some extent from both the societal values of individuals or groups of accountants as practitioners and those of institutions which influence or regulate the activities of individuals.

Institutional consequences may include direction and control of individuals' activities, and of values publicly promoted. For example, in describing cultural hegemony Gramsci claimed "the entire liberal ideology, with its strengths and its weaknesses, can be encapsulated in the principle of the separation of powers, and the source of liberalism's weakness then becomes apparent: it is the bureaucracy - i.e. the crystallisation of the leading personnel - which exercises coercive power" (Gramsci, 1971, p246). So institutional influence may not be equally representative of values held across society as a whole, and give undue prominence to the values of leaders.

Accounting values identified by Gray (1988) are as follows:

Professionalism versus Statutory Control. This means that individual professional judgment and professional self-regulation is preferred to compliance with prescriptive legal requirements and statutory control. It is considered an important value dimension to accounting because accountants are expected to exercise professional judgements to a varying 
degree in different countries. Gray (1988) linked professionalism to individualism and uncertainty-avoidance, and to a lesser extent to power-distance. He went on to conclude that "the higher a country ranks in terms of individualism and the lower it ranks in terms of uncertainty avoidance and power distance then the more likely it is to rank highly in terms of professionalism" (p.9). Since Russia is ranked low on individualism, and high on uncertainty avoidance and power distance, Russian accountants can be expected to rank low in terms of professionalism and give preference to statutory control in accounting.

Uniformity versus Flexibility. This means a preference is given to the consistent use of uniform accounting practices between companies over time as opposed to being flexible and adapting to an individual company's circumstances. This is considered an important value dimension to accounting as uniformity is linked directly to comparability, which is one of the fundamental characteristics of accounting principles. Gray argued that uniformity is strongly linked to uncertainty avoidance and individualism/collectivism, and again to a lesser extent to power-distance. Gray stated that "the higher a country ranks in terms of uncertainty avoidance and power distance and the lower it ranks in terms of individualism then the more likely it is to rank highly in terms of uniformity" (p.10). Since Russia is ranked high on uncertainty avoidance and power distance, and low on individualism, according to Gray's view, Russian accountants can be expected to have a preference for uniformity.

Conservatism versus Optimism. This refers to being cautious when measuring the uncertainty of any future events rather than taking a more optimistic and risk-taking approach. Gray went on to conclude that "the higher a country ranks in terms of uncertainty avoidance and the lower it ranks in terms of individualism and masculinity then the more likely it is to rank highly in terms of conservatism"(p.10). Since Russia is ranked high on uncertainty avoidance and low on individualism and masculinity, Russian accountants are expected to give a higher preference to conservatism. 
Secrecy versus Transparency. This refers to a strong sense of confidentiality where information about a company is only disclosed to its management and financing individuals in preference to a transparent and publicly accountable approach. The societal value dimensions that Gray linked secrecy with most closely are uncertainty avoidance, power distance and individualism/collectivism, and to a lesser degree with masculinity. His conclusion related to this issue was that "the higher a country ranks in terms of uncertainty avoidance and power distance and the lower it ranks in terms of individualism and masculinity then the more likely it is to rank highly in terms of secrecy" (p.11). Since Russia is ranked high on uncertainty avoidance and power distance and low on individualism and masculinity, Russian accountants are expected to prefer secrecy to transparency.

One of the limitations of Gray's work was the lack of empirical evidence for the link between societal values and accounting values. Hence, Gray (1988) proposed that the accounting values need to be operationalised and dependent variables need to be created. The hypotheses need to be empirically tested to establish the link, and any additional variables identified. Salter and Niswander (1995) established that Gray's model has statistically significant explanatory power with regards to financial reporting practices, however it was weak in explaining existing professional and regulatory structures from a cultural perspective.

Overall, Salter and Niswander (1995) found that all of the hypothesised links between accounting values and the uncertainty avoidance culture construct exist. However, other cultural dimensions are not as closely related to accounting values as Gray predicted, with individualism being significantly related only to secrecy, masculinity only relating to measurement process and rule setting, and power distance not being related to accounting values at all. These results have important implications with regards to harmonisation of accounting standards and practices around the world. Particularly, Salter and Niswander (1995) observed "high uncertainty avoidance societies preferring a system that is relatively 
secretive and conservative with auditors as state functionaries. Thus at the supranational level, countries at opposite ends of the cultural scale are likely to have opposing views on what are appropriate harmonised standards for measurement and disclosure" (p.389). Subsequently Chanchani and Willett (2004) constructed an accounting value survey (AVS) following the form and content of the original survey used by Hofstede (1980). The survey was distributed to the users and preparers of financial statements in India and New Zealand. The findings suggest some support for Gray's model with professionalism coming out as the most reasonable accounting value construct. The uniformity value construct was found to be closely linked with secrecy, suggesting that uniformity should be included in a wider accounting value construct. The secrecy construct did emerge but less strongly than professionalism and uniformity. Furthermore, conservatism appears to consist of two parts of disclosure and measurement (Chanchani and Willett, 2004).

\section{International Accounting Research}

Doupnik and Salter (1995) argued that there are three elements that determine a country's accounting development: the external environment, cultural values and the institutional structure.

The elements are expected to vary across different countries creating differences in accounting systems internationally. The authors stressed that "culture permeates the various systems that constitute the institutional structure, impacting on accounting practice through norms and values held by members of the accounting system and norms and values held by members of other systems with which the accounting system interacts" (1995, p.193).

Nobes (2006) investigated systematic differences in the practice of IFRS between German listed companies and UK ones. With regards to the motives, these countries have different financial, legal and tax systems and Nobes argued that "national accounting traditions are 
likely to continue into consolidated reporting where scope for this exists within IFRS rules" (2006, p.235).

Ding et al (2005) investigated the role of a country's culture and legal origin as an explanation for the differences between local GAAP (Generally Accepted Accounting Principles) and IAS as they were in 2001. They based their study on the "GAAP 2001" survey (Nobes, 2001) and classified accounting differences as either "divergence", referring to inconsistencies due to varying treatments of same accounting issue between GAAP and IAS, or "absence", referring to a lack of a specific rule in national GAAP as compared to IAS (p.330). Ding et al (2005) used cultural dimensions identified by Hofstede (1980) and Schwartz (1994) together with a country's legal origin. The findings suggested that cultural values were associated with divergence and had a bigger impact on it then the legal origin. However, they have found no relationship between absence and either cultural dimensions or legal origin.

Russia has joined the implementation of IFRS and started harmonising Russian Accounting Standards (RAS) with IFRS. In 2005 the Organisation for Economic Co-operation and Development (OECD) published a paper outlining 25 recommendations for Russia aiming at facilitating its transition to IFRS. The recommendations concerned four different areas. It was recommended that IFRS should first apply only to the companies of major national interest such as large listed companies and regulated financial institutions. The introduction of clear endorsement criteria was also suggested. Russia was advised to make enforcement of IFRS its main concern by developing acceptable audit standards and practices. Finally, it was recommended that Russia should revise its statutory accounting in order to bring it closer to IFRS in the mean time, and to have a single set of standards in the future. Since announcing its intention to adopt IFRS Russia experienced some problems in implementation of its accounting reform programme. To better understand the current state of accounting standards 
harmonisation process in Russia, it is important to look back at the history of accounting development in this country.

\section{History of Russian Accounting Development}

In the late eighteenth century Catherine II's reign brought the reforms of administrative and social restructuring. Concern for the economy became the focal point, the first book on double-entry accounting was published and formal education in commerce also began (Motyka, 1990). An Italian double-entry three-book accounting system was popular with the private sector, however a single entry rather than double-entry bookkeeping system was still largely prevalent under Catherine II and stayed so until the second half of the nineteenth century. "This was the main reason why the Russian empire fell 350 years behind Western Europe with regard to the introduction of Italian double-entry bookkeeping" (Liberman and Eidinov, 1995, p.779). "Ignorance of bookkeeping was a major cause of business failures in Russia and a great deterrent to the growth of firms. Many a successful enterprise collapsed after the death of its founder because his heirs could not carry on for want of account books" (Gorelik, 1971, p.1).

A major change came in 1918 post the Bolshevik revolution when the monarchy was abolished and new socialist state created. Under Lenin's rule socialist accounting was required to have four characteristics: openness, mass character, responsibility and simplicity (Enthoven et al, 1992). However, a government was also recognised as having a role in control exercised through the law: "Because one is acting essentially on economic forces, reorganising and developing the apparatus of economic production, creating a new structure, the conclusion must not be drawn that superstructural factors should be left to themselves..." (Gramsci, 1971, p247). With the advent of command and an administrative regime that enterprises had to follow, the accounting procedures established in the market-based economies were distorted in Russia. "Numerous distortions in the financial and management 
aspects of accounting and poor servicing of operations involving material and technical supplies seriously affected the accuracy, authenticity and effectiveness of accounting" (Liberman and Eidinov, 1995, p.781). The practice of accounting became formal and was seen as a labour-intensive and tedious job. The contents of the accounting statements were determined by the government on a yearly basis and the order of the accounts presentation was complicated.

It is evident that the accounting system relieved a Soviet accountant from any decisionmaking as the government regulated all aspects of it. All accountants had to do was gather and provide plenty of statistical and economic data that was needed for controlling the Soviet economy and aid in economic planning (Enthoven et al, 1992). The accounting system was not designed to provide information about organisations' performance and aid managers' decision-making and control.

"Since 1987 the accounting system has been drifting closer and closer towards the international standards and has been absorbing the advantages of Western accounting" (Liberman and Eidinov, 1995, p.782). The period of the late 1980s and early 1990s was characterised by perestroika, the economic and political reform started by Gorbachev. During that period the USSR disintegrated into separate independent states. The Russian Federation as it is known today was formed. Under perestroika the country underwent a transition from a planned to a market economy. From an accounting perspective such a transition means "changing the role of accounting from a tool of central planning to a method of managerial accounting, serving as a catalyst for efficiency and effectiveness on the enterprise level" (Shama and McMahan, 1990, p.155).

By the late 1990s the Russian government started the accounting system reform with the introduction of the "Programme for the reformation of accounting in accordance with 
International Accounting Standards" (Decree of the Russian Federation, 1998). The programme aimed at bringing the Russian accounting system in line with the market economy requirements and IFRS. The plan of the programme stated that by the year 2000 the whole system would be reformed (Preobragenskaya and McGee, 2004). The following changes were made during the reform: A new set of accounting standards was introduced claiming to be in line with IFRS; the emphasis on accounting procedures of how to make entries was replaced with emphasis on the financial reporting process and disclosure of information; the separation of tax and financial accounting occurred, hence from $1^{\text {st }}$ January 2004 taxes are no longer calculated based on financial reporting data; the Institute of Professional Accountants of Russia was founded in 1997 - Russia's first professional accounting organisation; changes to accounting education were introduced together with professional accounting certification and incorporation of a course on IFRS into the university curriculum; and in addition, the institution of auditing was founded and the law 'On Auditing' came into force (Preobragenskaya and McGee, 2004).

Nevertheless, the reform of accounting transition was hit by numerous problems, in the nature of delays and an alleged ambivalence towards the desirability of IFRS, that stalled the planned implementation of IFRS and harmonisation of Russian Accounting Standards (RAS) with IFRS. The transition became "a classic example of administrative hurdles in action" (Khakamada, 2003, p.1). According to the Ministry of Economic Development (MED), the transition to IFRS was supposed to follow a three stage plan. Firstly, IFRS would have been adopted by those organisations listed on the Russian stock exchange. During the second stage IFRS would be adopted by the state-controlled organisations and insurance companies. Finally, in the third stage the rest of the organisations of major national interest, including those listed on foreign stock exchanges and those using other international accounting standards such as US GAAP would adopt IFRS (Sitcina, 2004). 
'IAS Plus' updates (Deloitte Touche Tohmatsu, 2003) state a plan was given government approval in 2003, requiring IFRS reporting to be extended to non-listed, but excluding small, companies by 2007. A bill requiring IFRS reporting by companies with more than one subsidiary was approved by the Duma in October 2004, and passed through two readings, but failed at the third in December. By February 2005, (Deloitte Touche Tohmatsu, 2005) this bill was reported to have stalled, with claims in the 22 February editorial of the business newspaper Vedomosti "that neither the business community nor government is ready for transition to IFRS" because "there are no incentives for transparency and there are technical difficulties for implementation that may cause chaos in the reporting rather than increase investment attraction". The 2004 law on consolidated financial statements, requiring banks, insurance companies, and companies with shares traded on a domestic stock exchange to report consolidated results under IFRS was signed into law in summer 2010, with a window for implementation from 2012 to 2015 (Deloitte Touche Tohmatsu, 2010). IFRS based financial statements would be produced in addition to statements produced using Russian Accounting Standards, rather than in place of them.

The length of the period of adoption for IFRS in Russia is similar to that in Canada over the same period, a difference being that Canada has had a consistent target year of 2011 for implementation established since 2006 (Deloitte Touche Tohmatsu, 2006), rather than a gradual slippage of the implementation date.

It has been claimed by Gavrilenkov et. al, (2004) that the corporate sector may not necessarily perceive a change to IFRS as beneficial. In a system where vertically integrated conglomerates "chaebols" operate, financial resources may be allocated through affiliated banks. In these circumstances political and business elites may pursue their mutual interests through co-operation, rather than promote an active financial market which requires comparable information such as that IFRS may help companies provide. 
Since 2004 banks and listed companies have been required to prepare their financial statements in accordance with IFRS. Banks are governed by the Central Bank of Russia, and are therefore a separate case on their own. Public listed joint-stock companies are required to produce their consolidated statements according to IFRS, however their individual financial statements must be prepared in accordance with RAS. Therefore, these companies have to produce two sets of Annual Reports - one in IFRS and one in RAS.

As at 2009, there were significant differences identified between Russian Accounting Standards and International Financial Reporting Standards. PricewaterhouseCoopers (2009) have updated the GAAP 2001 study on international accounting differences the summary of which is presented in Table 1. The main differences between RAS and IFRS are as follows:

- There is no concept of inflation accounting in RAS.

- Stand-alone company financial statements are treated as superior to consolidated financial statements, which are often not prepared at all.

- There are no rules for impairment of assets and business combinations in RAS.

Table 1:

Russian accounting may differ from that required by IFRS/IAS because of the absence of specific rules on recognition and measurement in the following areas: 


\begin{tabular}{|c|c|}
\hline Provisions regarding business combinations accounted for as acquisitions & IFRS 3 \\
\hline Consolidation of special purpose entities & SIC 12 \\
\hline $\begin{array}{l}\text { The restatement of financial statements of a company reporting in the currency of } \\
\text { hyperinflationary economy in terms of the measuring unit current as of the balance sheet date }\end{array}$ & IAS 29 \\
\hline The translation of financial statements of hyperinflationary subsidiaries & IAS 21 \\
\hline The treatment of accumulated deferred exchange differences on disposal of a foreign entity & IAS 21 \\
\hline De-recognition of financial assets & IAS 39 \\
\hline Recognition of operating lease incentives & $\begin{array}{l}\text { IAS17, } \\
\text { SIC } 15\end{array}$ \\
\hline Accounting for defined benefit pension plans and some other types of employee benefits & IAS 19 \\
\hline Accounting for an issuer's financial instruments & $\begin{array}{l}\text { IAS 32, } \\
\text { IFRS 2, } \\
\text { IFRS } 7\end{array}$ \\
\hline Accounting for derivative financial instruments & IAS 39 \\
\hline Hedge accounting & IAS 39 \\
\hline Accounting for long-term assets held for disposal & IFRS 5 \\
\hline \multicolumn{2}{|l|}{ There are no specific rules requiring disclosures of: } \\
\hline The fair values of financial assets and liabilities & $\begin{array}{l}\text { IAS 32, } \\
\text { IFRS } 7\end{array}$ \\
\hline The fair values of investment properties & IAS 40 \\
\hline Certain segment information & IAS 14 \\
\hline Summarised financial information on associates & IAS 28 \\
\hline Extensive disclosures on business acquisitions/disposals & IFRS 3 \\
\hline $\begin{array}{l}\text { Significant management judgements made in the process of applying the entity's accounting } \\
\text { policies and key sources of estimation uncertainty }\end{array}$ & $\begin{array}{l}\text { IAS } 1, \\
\text { IAS } 36\end{array}$ \\
\hline \multicolumn{2}{|c|}{$\begin{array}{l}\text { There are inconsistencies between Russian Accounting Rules and IFRS that could lead to differences for } \\
\text { many enterprises in certain areas. Under RAS: }\end{array}$} \\
\hline
\end{tabular}




\begin{tabular}{|c|c|}
\hline Goodwill is calculated by reference to the book value of acquired assets & IFRS 3 \\
\hline $\begin{array}{l}\text { Proportionate consolidation may be used for subsidiaries in which the parent holds } 50 \% \text { or less } \\
\text { of the voting shares }\end{array}$ & IAS 27 \\
\hline $\begin{array}{l}\text { The useful life of property, plant and equipment is usually determined using periods prescribed } \\
\text { by the government for tax purposes }\end{array}$ & IAS 16 \\
\hline $\begin{array}{l}\text { Finance leases are generally defined in legal terms and the right of capitalisation is given to a } \\
\text { lessor or a lessee by a contract }\end{array}$ & IAS 17 \\
\hline Derivative financial assets and liabilities are not recognised & IAS 39 \\
\hline Provisions can be established more widely or less widely under IFRS & IAS 37 \\
\hline $\begin{array}{l}\text { The correction of errors is included in the determination of the net profit or loss for the } \\
\text { reporting period, but disclosed separately }\end{array}$ & IAS 8 \\
\hline $\begin{array}{l}\text { Revenue recognition rules do not differentiate between exchanges of goods of a similar nature } \\
\text { and value and exchanges of dissimilar goods, and do not discuss adjustment for the amount of } \\
\text { cash or cash equivalents transferred in exchanges for dissimilar goods }\end{array}$ & IAS 18 \\
\hline \multicolumn{2}{|l|}{ In certain enterprises, the following issues could also lead to differences from IFRS: } \\
\hline Some parent companies do not prepare consolidated financial statements under IFRS & IAS 27.10 \\
\hline $\begin{array}{l}\text { In the definition of control, it is not required that the ability to govern decision-making be } \\
\text { accompanied by the objective of obtaining benefits from the entity's activities }\end{array}$ & IAS 27 \\
\hline Certain subsidiaries may be excluded from consolidation beyond those referred to in IFRS & IFRS 3 \\
\hline $\begin{array}{l}\text { A subsidiary that is a bank may be excluded from consolidation if it is dissimilar from the rest } \\
\text { of the group }\end{array}$ & IAS 27 \\
\hline $\begin{array}{l}\text { Internally generated brands and similar items can be capitalised if the enterprise has an } \\
\text { exclusive legal right }\end{array}$ & IAS 38 \\
\hline The realisable value of inventories is measured without deduction of selling costs & IAS 2 \\
\hline
\end{tabular}

\section{Differences between Russian Accounting Standards and International Financial}

\section{Reporting Standards}


Therefore, after years of transition and attempts of harmonisation of RAS in line with IFRS the differences still exist, and Russia still experiences difficulties in implementing international standards. Decades of planned economy "left Russia with a day-to-day 'Soviet culture' where the first reactions to a new rule is to seek ways to manoeuvre around the rule and to devise ways to successfully cheat. The still extant bureaucracy is not convinced of the desirability of installing and implementing a new set of international accounting rules, especially, when they cannot see how it will benefit them personally" (Sarikas and Djatej, 2005, p.57).

On top of this, the new harmonised Russian accounting rules were also met with resistance. A survey of 1,040 Russian business enterprises found that $31 \%$ of respondents consider financial statements "not very useful for their enterprises" (Rozhnova, 2000, p.1). Hence a third of financial statements preparers do not see any benefits of financial reporting. Moreover, $93 \%$ of accountants stated that the primary purpose of financial accounting data collection is for tax reporting purposes. $57 \%$ of accountants also believe that the statements they produce do not provide a true picture of an organisation's financial position. The study also found that a fundamental problem lies in the difficulty of understanding the new standards and the lack of guidance for implementation of the new rules. "The perception of national accounting standards is difficult because of their inherent vagueness and ambiguity and lack of necessary explanations" (Rozhnova, 2000, p.2).

It is possible that RAS will never be the same as IFRS. "That is because Russian culture and Russian thought processes come into play" (McGee and Preobragenskaya, 2005, p.23). Accountants in Russia have become accustomed to being simply bookkeepers with only the job of filling out journal entries. Sarikas and Djatej (2005) assert that "the behavioural and cultural legacy of the Communist system explains in part the difficulties Russia has faced and will continue to face in achieving a successful implementation of the International 
Accounting Standards" (p.57), as well as complete harmonisation of Russian standards with IFRS.

Hence, one of the contributions of this study is to examine current perceptions of Russian accountants towards financial reporting under new harmonised Russian Accounting Standards based on Rozhnova's study (2000). Since these are the only compulsory standards, accountants in Russia should be well-versed in their application, as compared to their knowledge of IFRS. Accountants' attitudes towards RAS are expected to show how prepared they are towards full harmonisation and possible full transition to IFRS. Accountants' attitudes and perception should, in turn, also help achieve the main purpose of this study - to examine the impact of national culture on the harmonisation of RAS with IFRS, in order to explain the differences that still exist between the two sets of accounting standards. Hence the study will draw on the works of Hofstede $(1980,2001,2005)$ and Gray (1988). The following research questions are intended to be answered by this study and the research objectives are intended to be achieved:

1. What are the attitudes and perceptions of Russian accountants towards financial reporting under new 'harmonised' Russian Accounting Standards?

2. Does culture have an impact on harmonisation of Russian Accounting Standards with the International Financial Reporting Standards?

\section{Methodology}

The present study took the form of the interpretivism philosophy, also known as constructionism, or social constructionism. "Constructionism is helpful because it flags a basic tenet of the approach, namely, that reality is socially constructed" (Robson, 2002, p.27). Therefore, the interviewer adopted a role of interpretivist in seeking to understand the subjective reality of the participants in this study so as to make sense of and understand their 
motives, actions and intentions (Saunders, Lewis and Thornhill, 2003) relating to harmonization of Russian Accounting Standards with the International Financial Reporting Standards. The present study adopted an inductive research approach as it tried to build a theory from the data collected. According to Saunders, Lewis and Thornhill (2003, p.89) "induction emphasises: gaining an understanding of the meanings humans attach to events; a close understanding of the research context; the collection of qualitative data; a more flexible structure to permit changes of research emphasis as the research progresses; a realisation that a researcher is part of the research process; and less concern with the need to generalise."

The purpose of the enquiry of the current study is exploratory (Robson 2002, p.59), to find out what is happening with regards to the harmonisation of Russian and International Accounting Standards with the new cultural insight on the situation by asking questions to assess it in a new light.

\section{Research Participants}

Participants in the study were 53 company accountants from Russia. The companies they represented belonged to various industries such as airlines, telecommunications and metallurgy from various regions of Russia. Non-probability sampling was used to select the participants. Since the nature of the study is qualitative, no need for statistical analysis was established to answer the research questions and to reach the research objectives.

In order to answer the study's research questions it was important to select participants who would have experience of both Russian and International Accounting Standards. A purposive sampling approach (Berg, 2007) was required in order to identify subjects with an adequate working knowledge of accounting standards in use in Russia. Consequently, 209 listed jointstock companies were initially contacted. This type of company was chosen because they are required to provide their consolidated financial statements in accordance with IFRS, as well 
as prepare individual statements according to RAS. Those companies were chosen from an online RUSTOCKS database (www.rustocks.com) of Russian listed companies. This database provided the authors with a comprehensive list of companies, including their contact details. 53 positive responses were received. Hence, a non-probability self-selection sampling method was used in the study. The advantage of using this method was that it provided participants who were interested in the study and deemed it important. As a result, the participants were more likely to give honest answers and collaborate well with the author during the data collection process. This, in turn, increased the validity of findings.

\section{Data Collection}

The study involved collecting primary data using semi-structured telephone interviews. The exploratory nature of the research required primary data collection. A semi-structured interview was chosen as a method of data collection instead of a questionnaire because it allowed the author to better capture participants' perspectives. The authors believed that in order to answer the research questions and objectives a deep understanding of the issues being investigated was needed. Semi-structured interviews allowed the interviewer to probe the answers further and obtain more detailed responses from the participants, instead of giving them a set of questions with possible answers ready to be selected.

Interviews were conducted over the telephone, using Skype ${ }^{\circledR}$ software. Since one of the authors is a native Russian speaker, the interviews were conducted in that language without the need for a translator to be present, which ensured reliability in questioning and the recording of responses.

\section{Development of interview questions}

In order to answer research question 1 (RQ1), which is to explore Russian accountants' attitudes towards and perceptions of reporting under the Russian Accounting Standards, the 
present study drew on the work of Rozhnova (2000). The process of harmonising RAS with IFRS requires not only changing and modifying the local standards, but also keeping up with the International Accounting Standards Board's constant revisions of international standards. Therefore, the authors believed it was important to gather new data on the issues reported in Rozhnova's (2000) study. As a result, interview questions used to answer RQ1 were adopted from that study. During the last ten years accountants in Russia might be expected to have become used to using new RAS, as well as being familiar with IFRS. The authors wanted to gather accountants' attitudes and perceptions about new 'harmonised' RAS in order to see how open they were to change and how instilled were their beliefs. This, in turn, also helped the authors with partly answering the second research question (RQ2), and developing more relevant and focused interview questions for part 2 of the interview process (Lincoln and Guba, 1985), which became the main focus of the research. As per table 1 outlining the differences that still exist between Russian Accounting Standards and IFRS in 2009, the following areas were selected for consideration in the interviews;

1. Publications of financial reports.

2. Significant management judgements made in the process of applying the entity's accounting policies and key sources of estimation uncertainty.

3. Impairment of assets - IAS 36, in particular issue of 'fair value' accounting that also relates to differences between RAS and IAS 32 and IFRS 7.

Following on from the literature review, the present study drew on the works of Hofstede $(1980,2001,2005)$ and Gray (1988) in order to answer RQ2. Specifically, Gray's study was used to identify the link between differences in accounting standards described above and culture using the following 'accounting values': Professionalism versus Statutory 
Control; Uniformity versus Flexibility; Conservatism versus Optimism; and Secrecy versus Transparency.

International Financial Reporting Standards require accountants to exercise their professional judgements, to have a degree of flexibility when applying the standards, to be more optimistic, and finally, be highly transparent in their disclosure practices. On the other hand, Russian accountants are expected to show preference for statutory control, complete uniformity, conservatism in applying the standards and being reluctant to disclose information, hence not welcoming transparency. These differences were claimed by Gray (1988) to arise from the differences in cultures.

Therefore, using accounting issues identified above, interview questions were developed in order to identify if Russian accountants do display certain cultural values that consequently have impact on harmonisation of RAS with IFRS.

\section{Data Analysis}

Due to the qualitative nature of this study, primary data gathered from the interviews was analysed interpretatively. The analysis was conducted by interpreting Russian accountants' answers towards research interview questions by creating a link between their attitudes and perceptions with cultural accounting norms identified in previous research. An inductive naturalistic approach to data was taken to analyse the extent to which common preferences appeared in the content of respondents' answers (Miles and Huberman, 1994; Silverman, 2010). Therefore the authors felt that the nature of the interviews required us to adopt a discourse analysis paradigm. With this types of analysis, the subjectivist ontology was assumed as the interviewees perceptions to accounting information was linked to the cultural perspectives. 


\section{Findings}

The first part of the interview was concerned with finding Russian accountants' attitudes and perceptions towards the new 'harmonised' Russian Accounting Standards (RAS). The study found that $19 \%$ of participants saw no benefits in financial reporting. When probed and asked whether they thought it was useful for their organisations the answer was negative. However, the results show that a majority of accountants in Russia do consider financial reporting under RAS useful and beneficial for their organisations because it helps them to comply with statutory tax requirements. However, the majority (52\%) of interviewed accountants do not consider financial reporting useful for outside users. Moreover, they do not even know what categories of users request their financial statements and deem it unnecessary to know what information requirements are expected of them by the outside users.

Consequently, $72 \%$ of participants named tax reporting as the primary purpose of preparing financial statements in accordance with RAS. The most common response to that question was "Because it (reporting) has to be done!" When the author probed the topic further and asked if the interviewee thought that financial reporting could increase attractiveness of their organisation to potential investors, only $23 \%$ replied that they believed it could. The rest of the responses indicated that financial reporting under Russian Accounting Standards was not there to attract investors, but to keep tax authorities happy and ensure continuity of business operations.

Continuing the interview process, accountants were asked if they requested financial statements from other organisations, such as potential partners or big clients. Most of the interviewees (69\%) said "yes", however when probed further and asked if it was a 
compulsory procedure only $10 \%$ confirmed that it was. The rest of the accountants admitted that it was not "in their habit" to do so.

The interviewees were very reluctant to answer the question of whether the statements prepared by them presented true and fair picture of their organisation's financial position and reflected economic reality. Due to the sensitivity of the topic the interviewer did not pursue to get a response to that question if the interviewee expressed reluctance to discuss it. However, participants were more than happy to share their thoughts on the financial statements prepared by other organisations. All of the interviewees expressed that they believed other organisations do not provide true and fair financial statements. When probed further and asked "What does fair presentation of financial statements mean to you?" - $60 \%$ of the interviewed Russian accountants believed that the fair presentation of financial statements constitutes total conformity with rules and procedures required to be followed under RAS. However, the rest of the participants did not provide adequate answers to this question.

The lack of confidence in financial statements was further discussed with each interviewee. 91\% of participants still found RAS difficult to understand and use, due to lack of clear instructions and explanations. The study confirmed that such issues as the choice of depreciation methods and determination of a useful life of property, plant and equipment were still found to be ambiguous and difficult to understand, as they were ten years ago. Moreover, there was a unanimous consensus that having no choices in selecting various accounting treatments and having clear instructions would improve the standards considerably.

Next, the interviewees were asked about their working relations with managers from other departments in their organisations. This question was asked in order to find out whether Russian accountants gathered information from the management on how resourses were being used. $87 \%$ of the interviewees said they did not maintain proper contacts with managers from 
other departments. Furthermore, they did not believe it was necessary to discuss the contents of the explanatory notes to financial statements with the managers. A majority of the accountants explained that they get primary documents from managers in other departments, and it is their (accountants') job to record it in the right way within the accounting system. It became clear from the interviews that the only reason an accountant would contact a manager of another department, such as a purchasing manager, was because the documentation was not filled in properly and needed to be re-submitted so that it can be put through the system.

The following findings were obtained from research interview questions that were more directly linked with some of the current differences between RAS and IFRS, and designed to demonstrate preferences for certain cultural characteristics.

Most of the interviewed accountants (66\%) do not agree with the financial statements being published for the general public. Those accountants do not think that the publicity of financial disclosures benefit their organisations in any way. Moreover, publication of more than just compulsory financial information, such as risks faced by the organisation, position in the market, new product developments and corporate governance disclosures, was deemed an "unnecessary waste of time that would disclose too much information to our competitors". However, every single participant confirmed that their organisation publishes its annual reports on the internet. Moreover, in $90 \%$ of cases annual reports published on the internet are provided in both formats - under RAS and IFRS. The usefulness of these publications was once again disputed by many interviewed accountants. For example, this was a response of one of the accountants: "I do not know if anyone even looks at our reports on the internet. I am not responsible for publishing the reports online; it is a responsibility of technical IT staff".

Moving on with the interview, accountants were asked if they were comfortable with exercising their own professional judgement. A large majority (75\%) said "No". A general 
consensus on that matter was that there is no need to make own judgements while preparing financial statements, as there are rules that need to be followed, otherwise "you can break the law", was the response of many accountants. It is not a surprise then, that the majority of accountants expressed their preference for a clear set of rules and instructions.

The answers to the next question in the interview process re-affirmed Russian accountants' views on making professional judgements expressed above. Moreover, the author was made aware by the interviewees that according to one of the Russian accounting Standards (PBU 4/99 as it is called in Russia) on "Financial Reporting of Organisations" - in exceptional circumstances, accountants are allowed to depart from existing rules, while preparing financial statements. It is possible when the rules do not allow a full and fair presentation of financial position of the company to be formed. Furthermore, any departure from a prescribed rule needs to be disclosed in the explanatory notes to the accounts, giving full reasons for the change of treatment and how it affected the reported financial position of an organisation. The study found that none of the interviewed accountants have ever used this norm.

The interviews also revealed that accountants do not make an assessment of their organisation's ability to continue as a going concern because there are no clear instructions on how to do so. Many accountants replied that it was "not an accountant's job to do".

The study also found that accountants in Russia prefer to have a uniform set of accounts rather than a less prescribed format of IFRS. One of the most common explanations for this was because uniform accounts are "easier to follow". They were also deemed "more comparable" and "very systematic". Other reasons included providing clear evidence of where the items reported in the statements originate from to assist the tax authorities and audit firms in checking through the statements. Russian accountants do not consider it as their job 
to gather such external information as asset's market values. Nor do they consider it as their job to estimate future cash flows that can be derived from assets. All the interviewed accountants believe it is to be left to a financial analyst. However, only a third $(32 \%)$ of interviewed accountants deploy such measures and are aware of current market values for certain assets. Nevertheless, every single accountant interviewed declared that they keep up to date with changes in economic and legal environments as part of their day-to-day job.

Finally, when asked whether they could choose to recognise an asset at either its book value or at its fair value, a predominant majority $(60 \%)$ of participants chose book value. The reasons given for such a choice were "because it is documented", "it can be reliably and objectively measured", whereas fair value was deemed too subjective and required estimation. Moreover, the fair value of an asset was simply understood by those accountants to be its market value. Discussion

\section{Russian Accounting Standards - Practitioners’ Attitudes and Perceptions}

Overall, Russian accountants have a positive attitude towards financial reporting under new harmonised Russian Accounting Standards. Russian accountants still do not see financial reporting as a tool of communication with the outside users of financial statements. Their attitudes and perceptions need to change in order for the harmonisation process to continue successfully. The International Accounting Standards Board (IASB) "believes that further harmonisation can be pursued by focusing on financial statements that are prepared for the purpose of providing information that is useful in making economic decisions" (Framework document, IASB, 2001).

According to the IASB the objective of financial statements is "to provide information about the financial position, performance and changes in financial position of an entity that is useful to a wide range of users in making economic decisions" (Framework document, IASB, 2001). The findings show that accountants in Russia still think of accounting as means of tax 
reporting and gathering information for statistical purposes, and not for the benefit of external users. Their perceptions of the fair presentation of financial statements differ from that specified in IAS 1 - Presentation of Financial Statements (IASB, revised 2007). According to IAS 1 "fair presentation requires the faithful representation of the effects of transactions, other events and conditions in accordance with the definitions and recognition criteria for assets, liabilities, income and expenses set out in the Framework" (paragraph 15). This research revealed that accountants in Russian generally follow rules and instructions to the letter of the law which mirrors what the studies of Sarikas and Djatej (2005, p.57) called "Soviet Culture" which creates a culture of manoeuvring around rules and systematic cheating of the system. Hence why Russian accountants do not trust financial statements of other organisations.

Accountants still find the new harmonised Russian Accounting Standards difficult to understand and use. The accountants pointed out that they struggled due to lack of instructions and explanations. Just as was pointed out by Enthoven et al (1992) accountants used to be relieved from any decision-making as accounting was heavily regulated. Now, with the harmonisation of accounting standards new rules and practices emerge in Russian accounting that contain choices of treatment for certain items, such as depreciation. The practitioners in Russia show a clear preference for rigid instructions. This fits well with Gray's (1988) accounting value dimension of Professionalism versus Statutory Control. It means that Russian accountants prefer complying with prescriptive statutory control as opposed to exercising their own professional judgement. This signifies a cultural link to the accounting standards' harmonisation process.

Lastly, the first part of the interview brought to light the fact that accountants in Russia do not communicate with managers from other departments in their organisations, apart from making formal requests for primary documents that need to be put through the accounting system. 
These findings re-affirmed that Russian accountants' perception of financial reporting under the new RAS has not changed from the previous era of planned economy, and they still see themselves as bookkeepers only.

\section{Cultural Impact on Harmonisation of RAS with IFRS}

The main objective of the research was to establish if culture has an impact on harmonisation between Russian Accounting Standards and the International Financial Reporting Standards. The second part of the interview concentrated on some of the differences that still exist between the two sets of accounting standards despite Russia's attempts at bringing RAS in line with IFRS.

Accountants in Russia display reluctance to disclose financial information to the external users. One of the main reasons was found to be fear of disclosing too much information to competitors. Based on these findings, accountants in Russia display clear signs of a preference for Secrecy as opposed to Transparency, as identified by Gray (1988). Secrecy stands for "a preference for confidentiality and the restriction of disclosure of information about the business only to those who are closely involved with its management and financing" (Gray, 1988, p.8). According to Gray, Russia's cultural values of high uncertainty

avoidance and power distance, together with collectivist views make it more likely for accountants to display a preference for secrecy. The views expressed by Russian accountants in this study confirmed this prediction. Giving preference for secrecy has an impact on harmonisation of RAS with IFRS because it contradicts with an open and transparent approach adopted by the IFRS.

Differences still exist between RAS and IFRS. The absence of specific rules in RAS requiring disclosures of significant management judgements made in the process of applying the entity's accounting policies, and key sources of estimation uncertainty, was investigated. Russian accountants were found to be uncomfortable with exercising their own professional 
judgements. However, IFRS require accountants to use their judgements and make assumptions in many of the standards. The following specific examples are taken from IAS 1 - Presentation of Financial Statements (IASB, revised 2007):

According to paragraph 125 of IAS 1:

"An entity shall disclose information about the assumptions it makes about the future, and other major sources of estimation uncertainty at the end of the reporting period, that have a significant risk of resulting in a material adjustment to the carrying amounts of assets and liabilities within the next financial year. In respect of those assets and liabilities, the notes shall include details of:

(a) their nature, and (b) their carrying amount as at the end of the reporting period".

To determine the carrying amounts of some assets and liabilities accountants need to estimate the effects of uncertain future events on those assets and liabilities in the reporting period (IAS1, 2007, paragraph 126). IAS 1 clearly states that "the assumptions and other sources of estimation uncertainty disclosed in accordance with paragraph 125 relate to the estimates that require management's most difficult, subjective or complex judgements”.

The key words in these requirements are 'assumptions', 'judgements' and 'estimation uncertainty'. Based on the findings of this study, however, accountants in Russia would have a problem with these requirements. There exists a preference for a clear set of rules and instructions or Statutory Control as opposed to Professionalism. Gray (1988) described it as a preference for "compliance with prescriptive legal requirements" (p.8). In addition, Russia is a country that ranks high on uncertainty avoidance cultural dimension (Hofstede, 2005). Hence, any future uncertainties would be met with great caution by Russian accountants. Therefore, there is another problem of preference for Conservatism, that is "a preference for a cautious approach to measurement so as to cope with uncertainty of future events" (Gray, 1988, p.8). 
Another example of these preferences was tested, also based on requirements of IAS 1.

According to paragraph 19:

"In the extremely rare circumstances in which management concludes that compliance with a requirement in an IFRS would be so misleading that it would conflict with the objective of financial statements set out in the Framework, the entity shall depart from that requirement in the manner set out in paragraph 20 if the relevant regulatory framework requires, or otherwise does not prohibit, such a departure”.

The study found that this requirement has been incorporated into RAS. Nevertheless, Russian accountants do not use it because it requires exercising their own professional judgements. Moreover, paragraph 25 of IAS 1 requires the management of an entity to make an assessment of its ability to carry on as a going concern. It is one of the fundamental characteristics of presenting financial statements under IFRS. Assessment of a going concern requires managers to take into account future events, which are normally uncertain by their nature. Russian accountants do not make such an assessment due to lack of instructions on how to do so, and leave it to professional financial analysts.

All of the examples above together with the findings of the study demonstrate that Russia is not ready to adopt these disclosure requirements yet because Russian accountants show the cultural traits of high uncertainty avoidance and a clear preference for statutory control.

Russian Accounting Standards have always consisted of a uniform Chart of Accounts. According to PwC (2009) the process of recording accounting data is regulated centrally with a uniform Chart of Accounts created by government authorities. Gray (1988) predicted that a country that scores highly on such cultural dimensions as uncertainty avoidance and power distance and low on individualism, would be more likely to show a preference for uniformity. According to Gray $(1988, \mathrm{p} .8)$ it signifies "a preference for the enforcement of uniform accounting practices between companies and for the consistent use of such practices over time as opposed to flexibility in accordance with the perceived circumstances of individual 
companies". In contrast to RAS, IFRS have more flexibility in the presentation of financial statements to suit the circumstances of individual companies. It is evident in IAS 1 paragraphs 54 and 82 , which specify the minimum requirements for the information to be presented in the Statement of financial position and the Statement of comprehensive income. It provides a guide for the preparers of financial statements of what items shall be presented, but not an exhaustive list. Therefore, accountants applying IFRS can tailor financial statements to their company's needs, which cannot be done under RAS.

Differences between new harmonised Russian Accounting Standards and IFRS include the lack of rules for accounting for the impairment of some assets in RAS. Using specific examples taken from IAS 36 - Impairment of Assets, the existence of differences may be explained from a cultural perspective.

According to paragraph 9 of IAS 36:

"An entity shall assess at the end of each reporting period whether there is any indication that an asset may be impaired. If any such indication exists, the entity shall estimate the recoverable amount of the asset”.

The indications used in the assessment process are pointed out in paragraph 12 of the IAS 36. These indicators are taken from both internal and external sources of information, such as changes in the asset's market value. The list of indicators is not exhaustive and once again requires the exercise of professional judgement to be made. As has already been discussed, Russian accountants are uncomfortable with exercising professional judgements.

IAS 36 requires the estimation of the recoverable amount of an asset. The standard specifies in paragraph 18 that the recoverable amount of an asset is the higher of an asset's or cashgenerating unit's fair value less costs to sell and its value in use. Firstly, the concept of fair value is relatively new to Russian accounting systems. The present study has found that accountants consider an asset's market value to be its fair value. However, the IASB specifies it as "the amount for which an asset could be exchanged, or a liability settled, 
between knowledgeable, willing parties in an arm's length transaction" (IASB, 2006). While it is recognised in many cases market value will equate to fair value (Elliott and Elliott, 2011), this may be seen as an over simplification. Firstly, selling costs may need to be deducted, giving a value akin to net realisable value. Secondly, where there is in practice no active market an alternative value may be required for revalued assets, for example depreciated replacement cost. This definition implies more than just market valuations but its vagueness prevents Russian accountants from accepting it fully. Russian accountants interviewed in the study demonstrated unwillingness to recognise a responsibility to acquire market values, or to estimate a value based on future cash flows. It was also established that accountants prefer to use assets' book values.

The objective of this study was to establish if culture plays a role in harmonisation of Russian Accounting Standards with the International Financial Reporting Standards by gathering practitioners' perspectives. Culture was found to have an impact on harmonisation of RAS with IFRS. Russia's high rankings in such cultural dimensions as Power Distance, Uncertainty Avoidance and Collectivism have contributed to the development of certain preferences among Russian accountants that are deeply set in. Those preferences were found to be for statutory control, uniformity, conservatism and secrecy. During the decades of the Soviet system of planned economy an accountant's job was simply that of bookkeeping and following prescribed rules and instructions. It appears that this mindset is still present among many of the accountants in Russia.

This, in turn, stops Russian accountants from adopting some of the principles of IFRS because it requires them to make judgements and follow standards that in their opinions lack prescribed rules and instructions. Application of the International Financial Reporting Standards requires an approach which incorporates professional judgements, flexibility, optimism and complete transparency of disclosures. Therefore, if Russia wants to harmonise 
its standards with IFRS successfully and eliminate any differences that still exist between the two sets of standards, it needs to work at changing accountants' mindsets. Individual practitioners and regulators have been previously exposed to a political environment in which state control and direction is valued, whether to educate and plan (Gramsci, 1971), or pursue the interests of a controlling elite (Gavrilenkov, 2004). It appears that both accountants, as shown in this study, and institutions responsible for accounting regulation, from the literature, are subject to the influence of culturally related preferences, related to accounting preferences by Gray (1988). These preferences for statutory control, uniformity and secrecy, are aligned more closely with existing RAS than IFRS (PricewaterhouseCoopers, 2009) in the remaining areas of difference. This study does not claim that culture is solely responsible for the differences that still exist between Russian and International Accounting Standards, but it shows how the cultural values present in accountants' mindsets might influence the harmonisation process.

\section{References}

Akperov, I. and Maslikova, J. (2002), "Peculiarities of forming organisational culture in Russia”, in: Rozina, I.N. (Ed.), Theory of Communication and Applied Communication, Rostov-on-Don, Institute of Management, Business and Law Publishing, Issue 1, pp.5-8.

Bagaeva, A. (2008), "An examination of the effect of international investors on accounting information quality in Russia", Advances in Accounting, incorporating Advance in International Accounting, Vol. 24 No. 2, pp 157-161.

Baskerville, R.F. (2003), "Hofstede never studied culture", Accounting, Organisations and Society, Vol. 28 No. 1, pp.1-14.

Berg, B.L. (2007), Qualitative Research Methods for the Social Sciences, Boston, Pearson.

Chanchani, S. and Willett, R. (2004), “An empirical assessment of Gray's accounting value constructs", The International Journal of Accounting, Vol. 39 No. 2, pp.125-154. 
Decree of the Russian Federation (1998), Programme for the Reformation of Accounting in Accordance with International Accounting Standards, Government Decree \#283, dated $6^{\text {th }}$ March.

Deloitte Touche Tohmatsu (2003), Country and Regional Updates: Russian Federation, IAS PLUS, January, available at www.iasplus.com/country/russia.htm (Accessed 12 September 2011).

Deloitte Touche Tohmatsu (2005), Country and Regional Updates: Russian Federation, IAS PLUS, April, available at www.iasplus.com/country/russia.htm (Accessed 12 September 2011).

Deloitte Touche Tohmatsu (2006), Country and Regional Updates: Canada, IAS PLUS, August, available at www.iasplus.com/country/canada.htm (Accessed 12 September 2011).

Deloitte Touche Tohmatsu (2010), Country and Regional Updates: Russian Federation, IAS PLUS, August, available at www.iasplus.com/country/russia.htm (Accessed 12 September 2011).

Denscombe, M. (2007), The Good Research Guide for small-scale social research projects, 3rd ed. Maidenhead, Open University Press.

Djatej, A.M., Sarikas, R.H.S. and Senteney, D.L. (2008), "Accounting reform and the role of cultural and historical paradigms in transitional economies of Eastern Europe: The case of Russia", in: McGee, R.W. ed. Accounting Reform in Transition and Developing Economies, Springer Science and Business Media, pp.139-153.

Ding, Y., Jeanjean, T. and Stolowy, H. (2005), "Why do national GAAP differ from IAS? The role of culture", The International Journal of Accounting, Vol. 40 No. 4, pp.325-350.

Doupnik, T.S. and Salter, S.B. (1995), "External environment, culture, and accounting practice: A preliminary test of general model of international accounting development", The International Journal of Accounting, Vol. 30 No. 3, pp.189-207.

Elliott, B. and Elliott, J. (2011), Financial Reporting and Accounting, $14^{\text {th }}$ ed. Harlow, FT Prentice Hall, Pearson Education.

Enthoven, A.J.H., Sokolov, J.V. and Petrachkov, A.M. (1992), Doing business in Russia and the other former Soviet republics: Accounting and joint venture issues, Montvale, Institute of Management Accountants. 
European Union (2002) Regulation (ec) no 1606/2002 of the European parliament and of the council of 19 July 2002 on the application of international accounting standards, Official Journal of the European Communities (September 11), L.243/1 - L.243/4.

Gavrilenkov, E., Welfens, P.J.J. and Wieght, R. (Eds.) (2004), Economic opening up and growth in Russia: Finance, trade, market, New York, Springer Science and Business Media.

Gorelik, G. (1971), "Enterprise profit and profitability measurements: Soviet-American convergence", The International Journal of Accounting Education and Research, Vol. 6 No. 2, p.1.

Gramsci, A. (1971), Selections from the Prison Notebooks of Antonio Gramsci, trans. Hoare, Q. and Nowell Smith, G., London, Lawrence and Wishart.

Gray, S.J. (1988), "Towards a theory of cultural influences on the development of accounting systems internationally", Abacus, Vol. 24 No. 1, pp.1-15.

Harding, N., \& McKinnon, J. (1997), "User involvement in the standard-setting process: a research note of the congruence of accountant and user perceptions of decision usefulness", Accounting, Organizations and Society, Vol. 22 No. 1, pp. 55-67.

Hofstede, G. (1980), Culture’s consequences, Beverley Hills, Sage.

Hofstede, G. (2001), Culture's Consequences: comparing values, behaviours, institutions and organisations across nation,. London, Sage Publications.

Hofstede, G. and Hofstede, G.J. (2005), Cultures and organisations: software of the mind, New York, McGraw-Hill.

International Accounting Standards Board (IASB) (2001), Framework for the Preparation and Presentation of Financial Statements, London, IASB.

International Accounting Standards Board (IASB) (2006), Glossary of Terms, London, IASB.

International Accounting Standards Board (IASB) (2007), IAS 1 - Presentation of Financial Statements, London, IASB.

International Accounting Standards Board (IASB) (2004), IAS 36 - Impairment of Assets, London, IASB.

Khakamada, I. (2003), "Bills will not stifle red tape”, Moscow News, 30 $0^{\text {th }}$ April, p. 1. 
Kluckholn, C. (1951), "The study of Culture", in D.Lerner, \& H.D. Lasswell (Eds.) The Policy Sciences , Stanford, CA, Stanford University Press.

Lincoln, Y.S. and Guba, E.G. (1985), Naturalistic Inquiry, Beverly Hills, Sage.

Liberman, L.V. and Eidinov, A.M. (1995), "The development of accounting in tsarist Russia and the USSR", The European Accounting Review, Vol. 4 No. 4, pp.777-807.

McGee, R.W. and Preobragenskaya, G.G. (2005), "Problems of implementing International Financial Reporting Standards in a transition economy: A case study of Russia", in McGee, R.W. (Ed.) Accounting and Financial System Reform in a Transition Economy: A Case Study of Russia, New York, Springer, pp.7-40.

McSweeney, B. (2002), "Hofstede's model of national cultural differences and their consequences: A triumph of faith - a failure of analysis", Human Relations, Vol. 55 No. 1, pp.89-118.

Michailova, S. (2000), "Contrasts in culture: Russian and Western perspectives on organisational change", Academy of Management Executive, Vol. 14 No. 4, pp.99-112.

Miles, M.B. and Huberman, A.M. (1994), Qualitative Data Analysis: An Expanded Sourcebook, $2^{\text {nd }}$ ed. Thousand Oaks, Sage.

Motyka, W. (1990), "The impact of Western Europe on accounting development in tsarist Russia prior to 1800", Abacus, Vol. 26 No. 1, pp.36-62.

Nobes, C. (2001), GAAP 2001 - A survey of national accounting rules benchmarked against international accounting standards, IFAD, available at www.iasplus.com/en/resources/resource45 (Accessed 15 April 2012).

Nobes, C. (2006), "The survival of international differences under IFRS: towards a research agenda”, Accounting and Business Research, Vol. 36 No. 3, pp.233-245.

OECD (2005), Implementing International Financial Reporting Standards (IFRS) in Russia: 25 Recommendations to Facilitate the Transition to IFRS, Paris, OECD, available at www.oecd.org/document/22/0,3343,en_2649_34813 35686358_1_1_1_1,00.html (Accessed 25 May 2009).

Preobragenskaya, G.G. and McGee, R.W. (2004), "Converting the accounting system of a transition economy: a case study of Russia", International Journal of Accounting, Auditing and Performance Evaluation, Vol. 1 No. 4, pp.448-464. 
PricewaterhouseCoopers (2009), Doing business and investing in the Russian Federation, available at www.pwcglobal.com/ru (Accessed 5 July 2009).

Robson, C. (2002), Real World Research, $2^{\text {nd }}$ ed. Oxford, Blackwell.

Rokeach, M. (1973), The Nature of Human Values, New York, NY, Free Press.

Rozhnova, O. (2000), The problem of perception of the new Russian Accounting Standards, available at www.gaap.ru/biblio/icar/11200/014e.asp (Accessed 5 July 2009).

Russian Mentality: Uncertainty and Fatalism (2002), Pravda, 26 March, available at: http://english.pravda.ru/main/2002/03/26/27175.html (Accessed 15 July 2009).

Salter, S.B. and Niswander, F. (1995), "Cultural influence on the development of accounting systems internationally: A test of Gray's [1998] Theory", Journal of International Business Studies, Vol. 26 No. 2, pp.379-397.

Sarikas, R.H.S. and Djatej, A.M. (2005), "History and the Russian accounting transition", International Journal of Accounting, Auditing and Performance Evaluation, Vol. 2 No. 1/2, pp.54-66.

Saunders, M., Lewis, P. and Thornhill, A. (2003), Research Methods for Business Students, 3rd ed. Harlow, Prentice Hall.

Schwartz, S.H. (1994), "Beyond individualism/collectivism: New cultural dimensions of values", in Kim, U., et al (Eds.), Individualism and collectivism: Theory, method and applications, Thousand Oaks, Sage.

Shama, A. and McMahan, G. (1990), "Perestroika and Soviet Accounting: From a planned to a market economy", The International Journal of Accounting, Vol 25, pp.155-169.

Shlapentokh, V. (1996), "Early Feudalism - the Best Parallel for contemporary Russia", Europe-Asia Studies, Vol. 48 No. 3, pp.393-411.

Silverman, D. (2010), Doing Qualitative Research, $3^{\text {rd }}$ ed., London, Sage.

Sitcina, V. (2004) "Pravilo buhgaltera (The rule of accountant)", Vremya Online, $25^{\text {th }}$ March, available at www.vremya.ru/print/94771.html (in Russian) (Accessed 1 July 2009).

Søndergaard, M. (1994), "Hofstede's consequences: A study of reviews, citations and replications", Organisation Studies, Vol. 15 No. 3, pp.447-456. 
Straub, D., Loch, K., Evaristo, R., Karahanna, E., Strite, M. (2002), "Towards a Theory Based: Measurement of Culture", Journal of Global Information Management, Vol. 10 No. 1, pp.13-23.

Triandis, H. C. (1972), The Analaysis of Subjective Culture, New York, NY, Wiley 